\title{
世界の高分子工業と日本の高分子工業
}

\author{
(株)化学工業日報社
}

\begin{abstract}
合成樹脂，合成ゴムなどをはじめとする高分子産業における世界の需給構造が変化しつつ ある。川上のエチレンと同様にアジア, 中国, 中東諸国の勢力增大がその背景にある。欧 米のみならずわが国企業もこれら地域への拠点シフトを進めており，こうした中で，技術 開発力を活かした展開こそがわが国企業の生き残り策となる。
\end{abstract}

\section{1. 石油化学工業}

世界の石油化学工業は近年，他の製造業と同様に巨大 メーカーへの寡占化が着実に進みつつある。その主役はオ イルメジャー（国際石油資本）系の化学企業抢よび，安価 な天然ガスを武器とした中東産油国であり，「原料を持つ あの」による支配構造が鮮明化してきた。また, 競争の舞 台は世界であっと屯需要成長幅の大きいアジア地域，とり わけ中国に集中しており，その煽りを受けるかたちでわが 国石化産業は厳しい環境にさらされている。

化学産業は 1990 年代初頭まで, 石油化学, ライフサイ エンス, ファインケミカルなど複数の事業セクターを抱え る総合化学型の企業が世界の主流を占め, 米国, ドイッ, 英国, フランス, イタリアなど先進国を代表する総合化学 企業が，世界市場を群雄割拠する時代が永らく続いてき た。しかし，ベルリンの壁崩壊後のグローバル競争時代に なり，欧米企業が事業の選択と集中を進めたことに加え， 中東産油国が天然ガスをべースとした石油化学工業の拡大 を推進，1999 年から 2000 年にかけてサウジアラビアで 世界規模の石化設備がほぼ同時に 3 基完成したことなど により，競争優位企業による塞占化時代に突入した。

1990 年代半ば以降になると，欧米の総合化学型企業は 大規模合併や大胆な事業分割などを繰り返し，ライフサイ エンスやスペシャリティー・ケミカルなどに特化した巨大 企業が次々之誕生した。仏ローヌ・プーランと独へキスト の合併によるライフサイエンス企業「アベンティス」の誕 生 (1999 年) や, 英インペリアル・ケミカル (ICI) の企業 分割 (1993 年) と, その後のスウェーデンのアストラ社と の合併によるアストラ・ゼネカ社の誕生 (1999 年), スイ スのチバガイギーとサンドの合併によるノバルティスの誕 生（1996 年）などがその代表例だ。その一方で, 石化事業 はシェル, エクンンモービル, ブリティッシュ・ペトロー リアム (BP) といったオイルメジャーに集中していった。

Trend Analysis of Domestic and Global Polymer Industry
かつての総合化学企業で, 現在も石油化学をコアビジネス としている世界的な企業は，独BASF と米ダウ・ケミカ ルの 2 社にすぎない。

オイルメジャーや中東産油国の石化メーカーが，自らの 成長戦略として最重視しているのがアジア市場, とりわけ 中国市場だ。経済産業省の試算では，石化の基礎原料であ るエチレンの世界需要は, 2000 年実績の 8,890 万トンか ら年率平均 $5.1 \%$ 成長し， 2006 年に 1 億 1,9700 万トンに 達する。増加分となる 3,090 万トンのうち，40\% 強の 1,250万トンがアジア地域に集中しており，さらにその 69\% にあたる 860 万トンが中国での増加分となる。この ため，石化工業における世界制覇の鍵を握るのが，中国で のシェア確保といえる。

こうした背景から，生産設備の新増設計画む中東および アジア地域に集中している（表 1 4）。同じく経済産業省 の試算では, 世界のエチレン生産能力は 2000 年の 1 億 750 万トンから 2006 年には 1 億 2,870 万トンへと 2,120 万トン拡大するが，このうち中東で 410 万トン，中国で 470 万トンの拡大を見込んでいる。さらに，2006 年以降 にはイランを中心とした中東地域で新設計画が続出してい る。

石化製品は，一般的に品質格差が少ないため, 競争条件 が「価格」に集約される傾向が強い。さらに，製造コスト の大半を原料代が占めることから, 原料を握る者が圧倒的 な競争優位者となる。グローバル競争激化により価格の低 下傾向が続く中で, 強者への事業の塞占化は今後, さらに 進展していくことになろう。

\section{2. 合成ゴム}

世界の合成ゴム需要は，中期的に安定した伸びが期待さ れている。メーカーの集まりである国際合成ゴム生産者協 会 (IISRP) によると, 1998 年のピーク時に 822.6 万トン まで拡大した新ゴムベースでの合成ゴム消費量は 2001 年 
表 1 世界のエチレン設備能力（2000 年末）と 2001 年以降の新増設（化学経済より）

(単位: $1,000 \mathrm{t}$ )

\begin{tabular}{|c|c|c|c|c|c|}
\hline 地域・国 & 能 力 & 新増設 & 地域・国 & 能 力 & 新増設 \\
\hline \multicolumn{3}{|l|}{ アジア } & スロバキア & 200 & \multirow{7}{*}{$\begin{array}{l}310 \\
600\end{array}$} \\
\hline 日本 & 7,043 & 170 & $\begin{array}{l}\text { チェコ } \\
\text { ハンガリー }\end{array}$ & $\begin{array}{l}400 \\
360\end{array}$ & \\
\hline 中国 & 4,900 & 4,060 & ポーランド & $\begin{array}{l}360 \\
360\end{array}$ & \\
\hline 韓国 & 5,230 & 290 & ルーマニア & 200 & \\
\hline 台湾 & 2,365 & \multirow{3}{*}{200} & ユーゴスラビア & 200 & \\
\hline タイ & 1,730 & & クロアチア & 70 & \\
\hline インド & 2,430 & & & & \\
\hline \multirow{4}{*}{$\begin{array}{l}\text { マレーシア } \\
\text { シンガポール } \\
\text { インドネシア } \\
\text { 北朝鮮 } \\
\text { パキスタン }\end{array}$} & 960 & \multirow{4}{*}{$\begin{array}{l}600 \\
880 \\
(75)\end{array}$} & CIS・東欧合計 & 6,440 & 1,390 \\
\hline & 1,010 & & \multicolumn{3}{|l|}{ 北・南米 } \\
\hline & $(60)$ & & \multirow{7}{*}{$\begin{array}{l}\text { 米国 } \\
\text { カナダ } \\
\text { メキシコ } \\
\text { ブラジル } \\
\text { アルゼンチン } \\
\text { チリ } \\
\text { コロンビア } \\
\text { ペルー } \\
\text { ベネズエラ } \\
\end{array}$} & \multirow{3}{*}{$\begin{array}{r}26,810 \\
5,218 \\
1,420 \\
2,885\end{array}$} & \multirow{4}{*}{$\begin{array}{r}1,680 \\
450 \\
200 \\
625 \\
430\end{array}$} \\
\hline & (10) & & & & \\
\hline アジア合計 & 26,193 & \multirow[t]{2}{*}{6,200} & & & \\
\hline オーストラリア & 505 & & & 345 & \\
\hline 中東・アフリカ & & $\cdot$ & & $\begin{array}{r}60 \\
120\end{array}$ & \multirow{2}{*}{600} \\
\hline イラン & 694 & \multirow{3}{*}{$\begin{array}{l}1,620 \\
(115)\end{array}$} & & 5 & \\
\hline \multirow{3}{*}{$\begin{array}{l}\text { イスラエル } \\
\text { クウェート } \\
\text { カタール } \\
\text { サウジアラビア }\end{array}$} & 185 & & & 600 & 830 \\
\hline & $\begin{array}{l}650 \\
525\end{array}$ & & 北・南米合計 & 37,463 & 4,815 \\
\hline & 5,740 & \multirow{2}{*}{$\begin{array}{l}675 \\
800 \\
600\end{array}$} & \multicolumn{3}{|l|}{ 西欧 } \\
\hline \multirow{7}{*}{$\begin{array}{l}\text { UAE } \\
\text { イラク } \\
\text { トルコ } \\
\text { リビア } \\
\text { アルジェリア } \\
\text { エジプト } \\
\text { ナイジェリア } \\
\text { 南アフリカ }\end{array}$} & (150) & & \multirow{7}{*}{$\begin{array}{l}\text { ベルギー } \\
\text { フランス } \\
\text { ドイッ } \\
\text { イタリア } \\
\text { オーストリア } \\
\text { オランダ } \\
\text { ギリシャ } \\
\text { スイス }\end{array}$} & \multirow{2}{*}{$\begin{array}{l}1,900 \\
3,200\end{array}$} & \multirow[t]{2}{*}{230} \\
\hline & 400 & \multirow{6}{*}{$(100)$} & & & \\
\hline & 360 & & & 3,330 & \multirow{2}{*}{$\begin{array}{r}40 \\
200\end{array}$} \\
\hline & 120 & & & 5,120 & \\
\hline & 300 & & & 2,110 & \multirow{8}{*}{270} \\
\hline & 330 & & & 345 & \\
\hline & 445 & & & $\begin{array}{l}20 \\
25\end{array}$ & \\
\hline 中東・アフリカ合計 & 9,749 & 3,695 & ポルトガル & 350 & \\
\hline \multicolumn{3}{|l|}{ CIS • 東欧 } & $\begin{array}{l}\text { スペイン } \\
\text { 英国 }\end{array}$ & $\begin{array}{l}1,450 \\
2,555\end{array}$ & \\
\hline ロシア & 3,160 & \multirow{4}{*}{340} & フィンランド & 290 & \\
\hline アゼルバイジャン & 360 & & ノルウェー & 430 & \\
\hline \multirow{3}{*}{$\begin{array}{l}\text { ベラルーシ } \\
\text { ウクライナ } \\
\text { ウズベキスタン } \\
\text { ブルガリア }\end{array}$} & 130 & & スウェーデン & 610 & \\
\hline & 550 & & 西欧合計 & 21,736 & 1,340 \\
\hline & 450 & 140 & 世界合計 & 102,086 & 17,440 \\
\hline
\end{tabular}

（資料：CEFIC，経済産業省など）

表 2 世界のエチレン系誘導品の 2000 年の生産能力と 2006 年の生産能力予測（エチレン換算值ベース）（単位：100万 $\mathrm{t}, \%$ ）

\begin{tabular}{|c|c|c|c|c|c|c|c|c|c|c|c|}
\hline & \multirow{2}{*}{ 世界計 } & \multicolumn{7}{|c|}{ アジア計 } & \multirow{2}{*}{ 西欧 } & \multirow{2}{*}{ 北米 } & \multirow{2}{*}{ 中東 } \\
\hline & & & 韓国 & 台湾 & 中国 & アセアン & インド & 日本 & & & \\
\hline $\begin{array}{r}\text { 能力 } \\
2000 \\
2006\end{array}$ & $\begin{array}{l}107.5 \\
128.7\end{array}$ & $\begin{array}{l}31.5 \\
38.8\end{array}$ & $\begin{array}{l}5.8 \\
5.9\end{array}$ & $\begin{array}{l}2.9 \\
3.9\end{array}$ & $\begin{array}{r}6.3 \\
11.0\end{array}$ & $\begin{array}{l}5.7 \\
7.4\end{array}$ & $\begin{array}{l}2.6 \\
2.7\end{array}$ & $\begin{array}{l}8.1 \\
7.8\end{array}$ & $\begin{array}{l}23.9 \\
25.9\end{array}$ & $\begin{array}{l}32.0 \\
35.0\end{array}$ & $\begin{array}{r}7.3 \\
11.3\end{array}$ \\
\hline $\begin{array}{c}\text { 増加幅 } \\
(100 \text { 万 } t)\end{array}$ & 21.2 & 7.3 & 0.1 & 1.0 & 4.7 & 1.7 & 0.1 & -0.3 & 2.1 & 3.0 & 4.1 \\
\hline $\begin{array}{c}\text { 伸び率 } \\
\text { (\%) }\end{array}$ & 3.0 & 3.6 & 0.3 & 4.9 & 9.7 & 4.4 & 0.9 & -0.5 & 1.4 & 1.5 & 7.7 \\
\hline
\end{tabular}

[中国 3 プラント新設を折り込み (経済産業省) ] 
表 3 世界のエチレン系誘導品の 2000 年の需要と 2006 年の需要予測（エチレン換算値）

(単位：100万 $t, \%)$

\begin{tabular}{|c|c|c|c|c|c|c|c|c|c|c|c|}
\hline & \multirow{2}{*}{ 世界計 } & \multicolumn{7}{|c|}{ アジア計 } & \multirow{2}{*}{ 西欧 } & \multirow{2}{*}{ 北米 } & \multirow{2}{*}{ 中東 } \\
\hline & & & 韓国 & 台湾 & 中国 & アセアン & インド & 日本 & & & \\
\hline 需要 & & & & & & & & & & & \\
\hline 2000 & 88.9 & 28.6 & 3.5 & 2.6 & 10.3 & 3.8 & 2.0 & 5.7 & 21.4 & 24.5 & 1.9 \\
\hline 2006 & 119.7 & 41.1 & 4.4 & 2.9 & 18.9 & 5.5 & 3.2 & 5.6 . & 24.7 & 32.7 & 3.0 \\
\hline $\begin{array}{c}\text { 増加率 } \\
(100 \text { 万 } \mathrm{t})\end{array}$ & 30.9 & 12.5 & 0.8 & 0.3 & 8.6 & 1.7 & 1.1 & -0.1 & 3.3 & 8.2 & 1.1 \\
\hline $\begin{array}{c}\text { 伸び率 } \\
(\%)\end{array}$ & 5.1 & 6.3 & 3.5 & 1.9 & 10.6 & 6.2 & 7.6 & -0.5 & 2.5 & 4.9 & 8.1 \\
\hline
\end{tabular}

(経済産業省)

表 4 四大沉用樹脂の新設計画

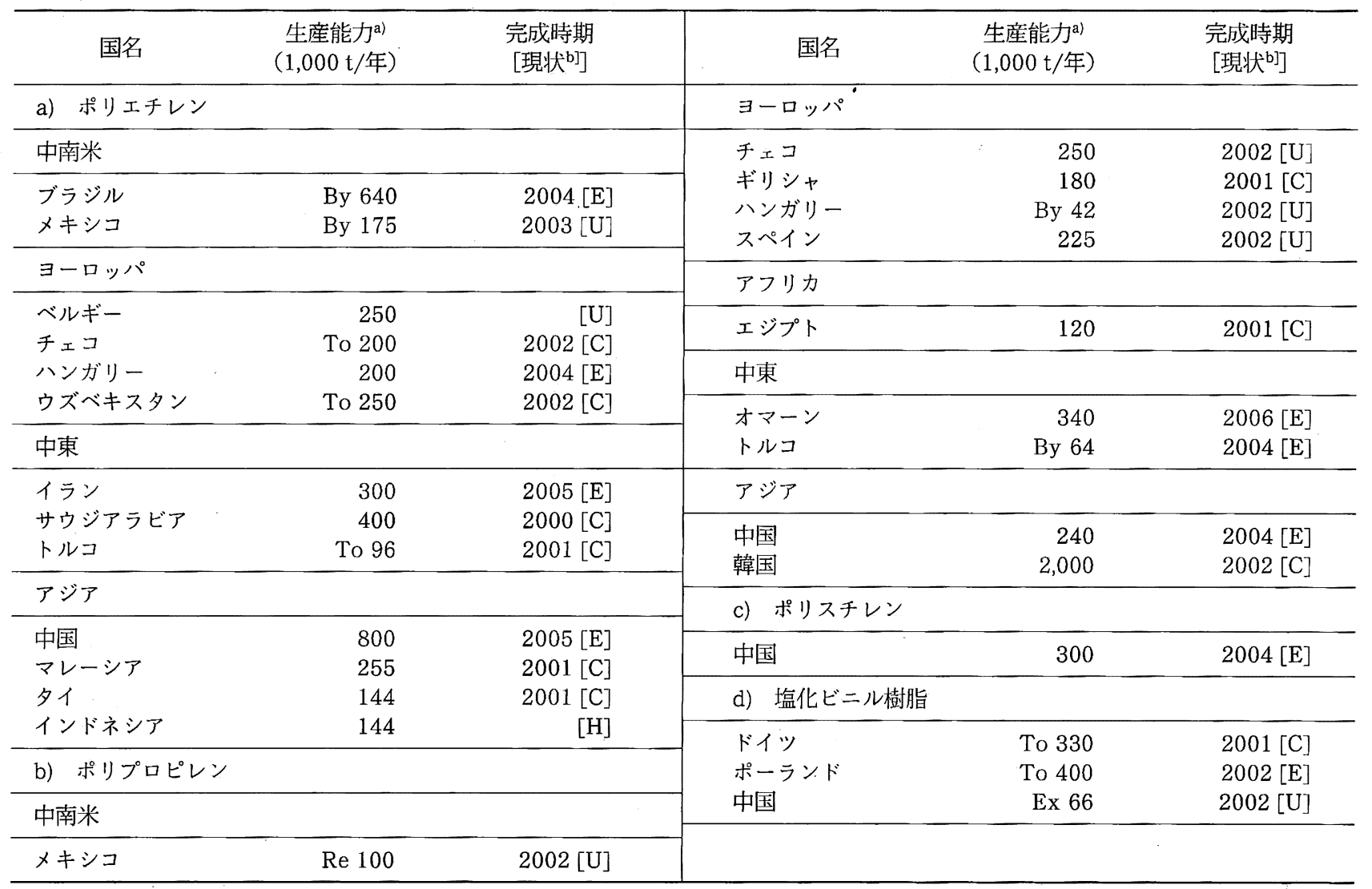

e) ナイロン (PA), PBT の新・増設計画

\begin{tabular}{llcc}
\hline \multicolumn{1}{c}{ 国名 } & 種類 & $\begin{array}{c}\text { 生産能力 } \\
(1000 \mathrm{t} / \text { 年 })\end{array}$ & $\begin{array}{c}\text { 完成時期 } \\
{\left[\mathrm{I}_{\mathrm{U}} \text { 状 }^{\mathrm{b}]}\right]}\end{array}$ \\
\hline ブラジル & $\mathrm{PA}$ & 10 & $2002[\mathrm{U}]$ \\
ドイッ & $\mathrm{PBT}$ & 80 & $2003[\mathrm{U}]$ \\
オランダ & $\mathrm{PBT}$ & 60 & $2004[\mathrm{E}]$ \\
スペイン & $\mathrm{PA}$ & 14 & $2002[\mathrm{U}]$ \\
中国 & $\mathrm{PA}$ & 23 & $2003[\mathrm{U}]$ \\
\hline
\end{tabular}

表中の記号の説明

a) By: 能力の増加 To: 工事完成後の総能力

Ex: 増設 Re: 既設の改良, 改造, ただし表中の数字は増加分か, または改造後の能力を示すかは不明:

b) $[\mathrm{P}]$ : 計画中 $[\mathrm{E}]$ : 設計・制作中 [U]: 工事中 [C]: 完成

[出典: Hydrocarbon Processing (June 2002)] 
には 776.2万トンまで落ち込んだ。しかし同じ IISRP の 予測では, 2006 年までの世界の同消費量は年率 $3 \%$ 以上 のペースで増加する。2001 年の実績が 5 年間で 905 万卜 ンに拡大するすので, 地域的にも最大市場の北米が平均 $2.1 \%$, 西欧同 1.7\%，アジア・太平洋同 3.3\% とほぼ全域 にわたって伸びが見込まれている（図 1,2）。

ただ，伸び率として大きいのはやはり中国で，2001 年 の 75.4 万トンから 108 万トンへと拡大し，年率 $7.5 \%$ に のぼる高成長をみせることになる。北米，西欧は 2006 年 時点であ市場規模第 1 位, 第 2 位を保つが, 今後の成長の けん引役は中国が担う。一方で競合する天然ゴムのとの対 比では同期間における天然品の伸びは年 $2.6 \%$ に止まるこ とから，合成品比率がさらに拡大することになる。

合成ゴムの品種別動きでは，スチレン・ブタジェンゴム (SBR), エチレン・プロピレンゴム (EPDM), アクリロニト

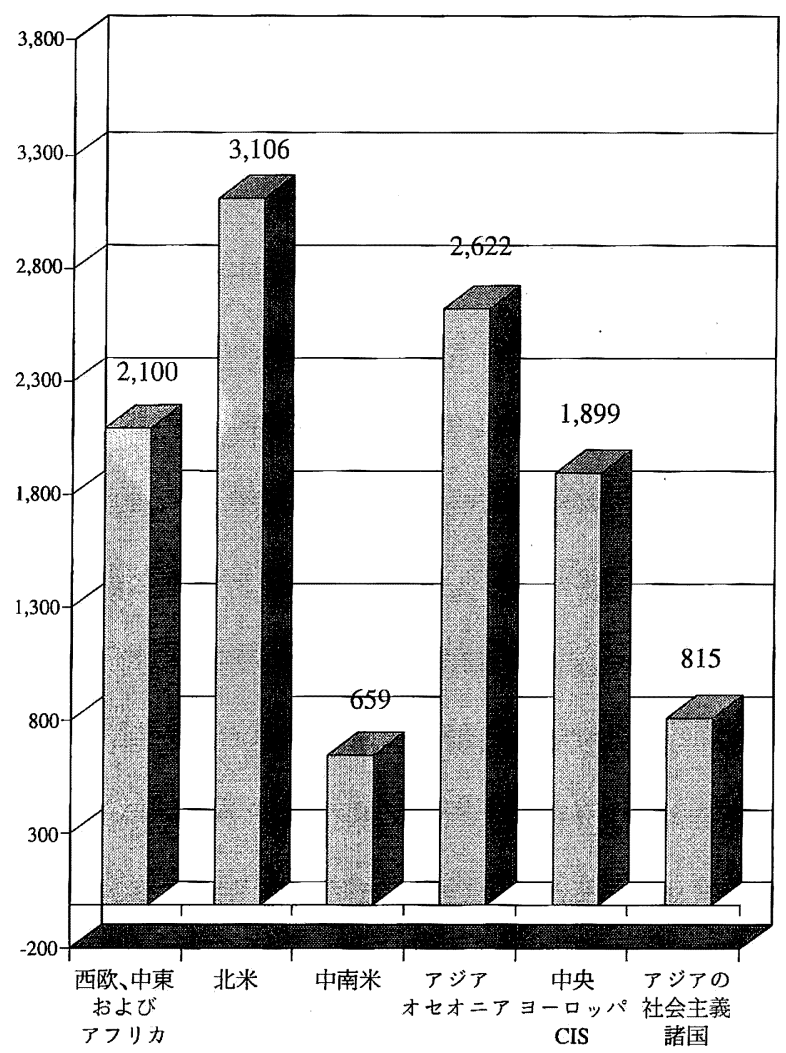

図 1 世界の合成ゴム生産能力（2001 年）(単位：1,000 t)
1992

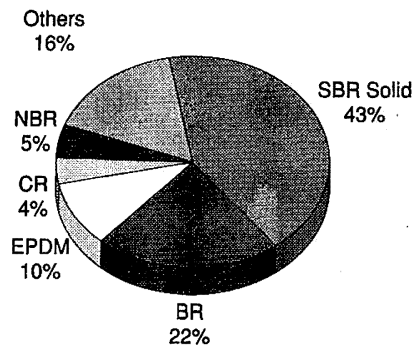

2001

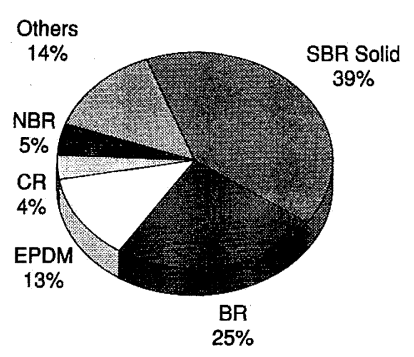

図 21992 年と 2001 年の合成ゴム消費量の品種別比率の推移
リル・ブタジェンゴム (NBR) などが好調に推移する（表 5〜7)。SBR は, 夕イヤ消費量の拡大を受けての需要増が 見込まれ，5年間 $16.8 \%$ の市場拡大。EPDM は，オレフィ ン系の熱可塑性エラストマー (TPO) の改質斉向けが大き く伸びていることから同 $20.3 \%$ とさらに高い成長を示す。 また NBR の成長は，燃料ホースなど自動車部品向けを軸 に同 $17.5 \%$ 増加する。こうした品種が大幅な需要増を期 待されるのに対し，クロロプレンゴム (CR) は塩素系製品 であるということあ手伝い，特に先進国で需要が減退， 5 年間で $7.6 \%$ しか成長できない。

（統計の出典はいずれも IISRP）

\section{3. 繊 維 産 業}

2001 年の世界における化繊生産は前年比 $0.8 \%$ 減の 2,768 万トンと, 1982 年以来 19 年ぶりにマイナス成長を 記録した（表 8)。先進国，なかであ米国の落ち込みが激し く，1996 年まで世界の化繊生産トップにあったが，年々 縮小傾向をたどり，2001 年は $17 \%$ の大幅減で 275 万卜 ンと, 西欧, 台湾に次ぐ 4 位に落ち込んだ。世界市場にお ける 2005 年の需要見通しでは，化合繊は年率 $4 \%$ の伸び が期待される成長産業との見方が多いなか，中国の独り勝 ちの状況が鮮明化している（図 3）。90 年代から生産量が 拡大し 97 年には世界 1 位に躍進。2001 年は同 19\% 増の 782 万トンと, 他国・他地域との差がますます広がってい る。

背景には, 1990 年代のアジアにおける戦略なき新増設 競争と，急速な中国の自給化進展による行き場を失った供 給過剰という状況がある。これは 1970 年代における欧米 企業の新規参入ラッシュと, 石油危機による需要減退抢よ びアジアからの輸入急増という状況之同様ともいえる。

日本の化学繊維生産量は直近のピークである 97 年の 180 万トン超に対し, 2001 年は 156.5 万トンと 1975 年 以来， 26 年ぶりの 160 万トン割れまで落ち込んでいる (表 9)。

国内各社では，設備の大幅な縮小や人員合理化などリス トラ策を実行に移しているが，旭化成のアクリル繊維撤 退, 帝人と米デュポンとのナイロン繊維合弁解消 など， 2002 年に入って相次いだ事業撤収は，低 迷が続く国内の衣料用繊維事業の舵取りがいよい よ難しくなってきたことを物語っている。

一方, 国内各社は衣料用繊維事業加ら自動車用 エアバッグや不織布，炭素繊維やアラミド繊維な どの高強力繊維といった非衣料用繊維事業に経営 資源を集中させ，繊維事業の収益底上げを図ろう としている。他国では手掛けることが難しい技術 力の高い製品づくりで, 再び世界市場での存在感 を示し始めている。 
表 5 世界の品種別ゴム消費量

\begin{tabular}{|c|c|c|c|c|c|c|c|c|c|c|c|}
\hline & 西欧, & アジア, & , オセア= & $=ア$, アフ & リカ，中本 & ， 北米， & 中南米 & & & & 増減 (\%) \\
\hline & 1992 & 1993 & 1994 & 1995 & 1996 & 1997 & 1998 & 1999 & 2000 & 2001 & $00 / 01$ \\
\hline \multicolumn{12}{|l|}{ 合成ゴム } \\
\hline SBR Solid & 2,419 & 2,352 & 2,495 & 2,574 & 2,619 & 2,685 & 2,810 & 2,781 & 2,652 & 2,460 & -7.2 \\
\hline $\mathrm{BR}$ & 1,249 & 1,282 & 1,410 & 1,471 & 1,497 & 1,578 & 1,569 & 1,628 & 1,633 & 1,513 & -7.3 \\
\hline EPDM & 601 & 586 & 660 & 676 & 706 & 736 & 784 & 818 & 844 & 796 & -5.7 \\
\hline $\mathrm{CR}$ & 240 & 233 & 255 & 248 & 237 & 244 & 244 & 239 & 237 & 222 & -6.3 \\
\hline NBR & 285 & 278 & 290 & 296 & 296 & 312 & 315 & 286 & 283 & 280 & -1.1 \\
\hline その他 & 930.4 & 902 & 957 & 1,005 & 995 & 1,039 & 1,066 & 913 & 905 & 855 & -5.5 \\
\hline 天然ゴム & 4,287 & 4,322 & 4,545 & 4,810 & 4,717 & 4,779 & 5,408 & 5,722 & 5,917 & 5,576 & -5.8 \\
\hline \multirow[t]{3}{*}{ 計 } & 10,011 & 9,955 & 10,612 & 11,080 & 11,067 & 11,373 & 12,196 & 12,392 & 12,619 & 11,839 & -6.2 \\
\hline & \multicolumn{7}{|c|}{ 中国/アジア CPEC, 中央ヨーロッパ, CIS（旧ソ連） } & \multicolumn{4}{|r|}{ 増減 $(\%)$} \\
\hline & 1992 & 1993 & 1994 & 1995 & 1996 & 1997 & 1998 & 1999 & 2000 & 2001 & $00 / 01$ \\
\hline \multicolumn{12}{|l|}{ 合成ゴム } \\
\hline 中国/アジア CPEC & $\begin{array}{r}1,962 \\
427\end{array}$ & $\begin{array}{r}1,174 \\
453\end{array}$ & $\begin{array}{l}640 \\
485\end{array}$ & $\begin{array}{l}800 \\
519\end{array}$ & $\begin{array}{l}747 \\
580\end{array}$ & $\begin{array}{l}749 \\
600\end{array}$ & $\begin{array}{l}775 \\
663\end{array}$ & $\begin{array}{l}661 \\
683\end{array}$ & $\begin{array}{l}715 \\
723\end{array}$ & $\begin{array}{l}745 \\
754\end{array}$ & $\begin{array}{l}4.2 \\
4.3\end{array}$ \\
\hline \multicolumn{12}{|l|}{ 天然ゴム } \\
\hline 中央ヨーロッパ\& CIS & 173 & 110 & 116 & 128 & 140 & 165 & 190 & 184 & 192 & 197 & 2.6 \\
\hline 中国/アジア CPEC & 708 & 750 & 803 & 805 & 810 & 937 & 900 & 920 & 1,220 & 1,250 & 2.5 \\
\hline \multirow[t]{3}{*}{ 計 } & 3,270 & 2,487 & 2,044 & 2,252 & 2,567 & 2,826 & 2,578 & 2,448 & 2,880 & 2,946 & 2.3 \\
\hline & \multicolumn{7}{|c|}{ 世界全体 } & \multicolumn{4}{|r|}{ 増減 (\%) } \\
\hline & 1992 & 1993 & 1994 & 1995 & 1996 & 1997 & 1998 & 1999 & 2000 & 2001 & $00 / 01$ \\
\hline 合成ゴム & 8,113 & 7,260 & 7,192 & 7,589 & 7,677 & 7,943 & 8,226 & 8,132 & 8,164 & 7,762 & -4.9 \\
\hline 天然ゴム & 5,168 & 5,182 & 5,464 & 5,743 & 5,667 & 5,881 & 6,498 & 6,708 & 7,155 & 7,023 & -1.8 \\
\hline 計 & 13,281 & 12,442 & 12,656 & 13,332 & 13,344 & 13,824 & 14,724 & 14,840 & 15,319 & 4,785 & -3.5 \\
\hline
\end{tabular}

表 6 地域別に見た合成ゴムの需要と需要予測

(単位: $1,000 \mathrm{t}$ )

\begin{tabular}{rrrlrr}
\hline 2001 & 2002 & 2006 & & $\begin{array}{r}\text { 年平均伸び率 } \\
2002-2006\end{array}$ & $\begin{array}{c}\text { 伸び率 } \\
2002-2006\end{array}$ \\
\hline 2,229 & 2,207 & 2,469 & 北米 & $2.1 \%$ & $10.8 \%$ \\
521 & 517 & 595 & 中南米 & $2.7 \%$ & $14.2 \%$ \\
1,759 & 1,780 & 1,918 & 西欧 & $1.7 \%$ & $9.0 \%$ \\
439 & 459 & 529 & CIS & $3.8 \%$ & $20.5 \%$ \\
306 & 314 & 366 & 中央ヨーロッパ & $3.6 \%$ & $19.6 \%$ \\
191 & 195 & 224 & 中東,アフリカ & $3.3 \%$ & $17.3 \%$ \\
1,587 & 1,620 & 1,871 & アジア,オセアニア & $3.3 \%$ & $17.9 \%$ \\
754 & 779 & 1,080 & 中国 & $7.5 \%$ & $43.2 \%$ \\
7,786 & 7,871 & 9,050 & 計 & $3.1 \%$ & $16.2 \%$ \\
\hline
\end{tabular}

表 7 品種別に見たゴムの需要と需要予測（単位： 1,000 t）

\begin{tabular}{lrrr}
\hline & 実績 & \multicolumn{2}{c}{ 予測 } \\
& 2001 & 2002 & 2006 \\
\hline SBR-Solid & 2,960 & 2,981 & 3,483 \\
Polybutadiene & 1,891 & 1,910 & 2,180 \\
EPDM & 841 & 854 & 1,012 \\
CR & 275 & 276 & 296 \\
NBR & 321 & 330 & 377 \\
その他の合成ゴム & 1,059 & 1,062 & 1,173 \\
SR-CIS 計 & 439 & 459 & 529 \\
合成ゴム計 & 7,789 & 7,871 & 9,050 \\
天然ゴム & 7,023 & 7,146 & 7,996 \\
計 & 14,809 & 15,017 & 17,048 \\
合成ゴムの割合 (\%) & 52.6 & 52.4 & 53.1 \\
\hline
\end{tabular}

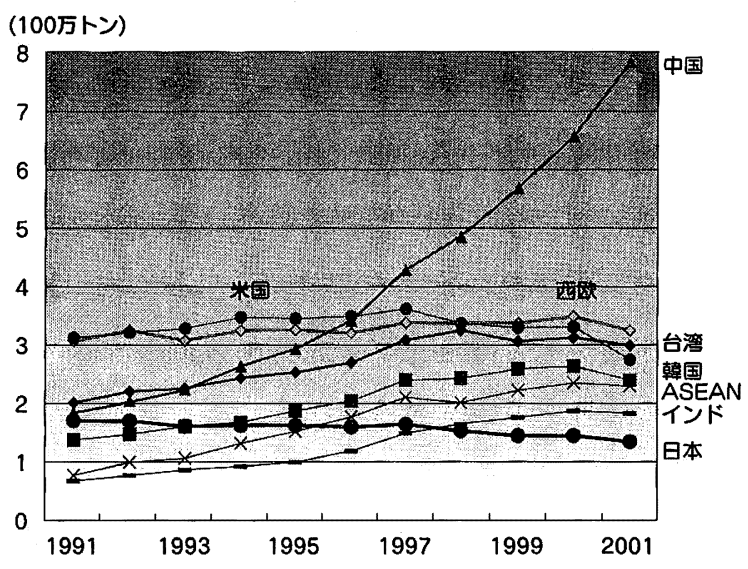

図 3 世界の主要地域の化繊生産 
表 8 世界の主要繊維の生産

\begin{tabular}{|c|c|c|c|c|c|c|c|}
\hline & \multirow{2}{*}{ 全繊維 } & \multicolumn{3}{|l|}{ 化学綫維 } & \multirow{2}{*}{ 綿 } & \multirow{2}{*}{ 羊毛 } & \multirow{2}{*}{ 絹 } \\
\hline & & & 合綫 & セルロース & & & \\
\hline 1996 & 43,278 & 22,245 & 20,062 & 2,183 & 19,480 & 1,482 & 71 \\
\hline 1997 & 46,274 & 24,939 & 22,653 & 2,286 & 19,846 & 1,414 & 75 \\
\hline 1998 & 45,449 & 25,421 & 23,167 & 2,254 & 18,551 & 1,400 & 77 \\
\hline 1999 & 46,724 & 26,375 & 24,281 & 2,093 & 18,887 & 1,380 & 83 \\
\hline 2000 & 48,799 & 27,923 & 25,706 & 2,216 & 19,400 & 1,390 & 86 \\
\hline 2001 & 50,237 & 27,688 & 25,576 & 2,112 & 21,100 & 1,363 & 86 \\
\hline $01 / 00(\%)$ & 2.9 & -0.8 & -0.5 & -4.7 & 8.8 & -1.9 & -0.2 \\
\hline 構成比 (\%) & 100.0 & 55.1 & 50.9 & 4.2 & 42.0 & 2.7 & 0.2 \\
\hline
\end{tabular}

表 9 日本の主要化学繊維の生産

$(1,000 \mathrm{t})$

\begin{tabular}{lrrrr}
\hline & \multicolumn{1}{c}{1999} & \multicolumn{1}{c}{2000} & 2001 & $01 / 00(\%)$ \\
\hline ポリエステル F & 386.6 & 382.6 & 364.1 & -4.8 \\
ポリエステル S & 278.4 & 282.0 & 263.7 & -6.5 \\
ナイロンF & 174.3 & 175.9 & 162.5 & -7.6 \\
アクリル S & 371.7 & 377.2 & 364.7 & -3.3 \\
\hline 合繊計 & $1,418.3$ & $1,432.6$ & $1,368.2$ & -4.5 \\
\hline レーヨンF & 17.9 & 14.8 & 5.2 & -65.1 \\
レーヨン & 75.9 & 70.9 & 65.3 & -7.9 \\
アセテート & 104.7 & 108.9 & 112.7 & 3.5 \\
\hline セルロース計 & 216.0 & 210.3 & 197.1 & -6.3 \\
\hline 化繊合計 & $1,634.3$ & $1,642.9$ & $1,565.3$ & -4.7 \\
\hline
\end{tabular}

（注）オレフィン，アセテートなどを含む.

\section{4. 塗料工業}

1999 年度, 前年比 $0.1 \%$ 增とわずかな伸びにとどまっ た日本国内の塗料生産量は, 翌年の 2000 年度に $1 \%$ 増の 189 万トン, 出荷量も同 $1 \%$ 増の 204 万トンを計上した。 ただ国内需要で約半分を占める建築用塗料が, 長引く同業 界の低迷で 2001 年度の国内生産量は $5.9 \%$ 減の 178.5 万 トンと減少を余儀なくされ出荷量も同様に約 $5 \%$ 減の 193 万トンによどまった（表 10～12）。景気浮上の糸口が つかめない 2002 年の日本経済。国内塗料業界む一進一退 の状況は変わらず直近の 2002 年 8 月 (単月) 国内塗料生 産量を見る之前年同期比 $6.9 \%$ 減の 13.78 万トン。 2002 年度トータルでは $5 \%$ を超える減少幅が予測されている。

シュリンクの続く国内生産の現況之相反し，日本塗料 メ一カーの海外生産量は, 飛躍的に増加しており国内加ら の「生産空洞化」が一段と鮮明になってきた。1990 年初頭 に 20 万トン超だった海外生産量は 95 年を境に増加。 2000 年の海外生産量は 1990 年比, $328 \%$ 増の 61 万トン に達した。とくに極東・アジア地域で海外生産量增加が著 しく日本塗料メーカーのアジア生産進出が 1995 年を契機 に加速していることがうかがわれる（表 13）。

アジア市場で, 日本の市場規模と数年で肩を並べるに 至った中国市場。現在，塗料業種でも最後の成長マーケッ
トとして大きな期待がかかっている。中国塗料市場は現 在, 生産量 200 万トン超, 沿岸部などでは GDP 7.9\%をは るかに上回る $20 \%$ 近い成長率を確保している。市場牽引 の主役は，ビルや一戸建て住宅ブームから生産量が増加し ている建築用塗料。内需を中心に 200 万トンのうち約 100 万トンが消費されている。向こう数年ベースでも 2 桁成長 の伸び率が確実視され，国内生産量 300 万トンのラインも 数年内に達するむのと見られている。

一方，引き続き世界最大の生産量をむつ米国市場は，景 気リセッション影響もあり 2000 年の需要数量は前年比 $0.5 \%$ 堌の約 606 万トンとなっている。2001 年も同様規 模の状況で推移しているが, 2002 年は一部の建築用塗料 や特殊塗料で伸びている品種むある。 
表 10 各種塗料の生産量および比率

\begin{tabular}{lrc}
\hline \multicolumn{1}{c}{ 種類 } & $\begin{array}{c}\text { 生産量 } \\
(1,000 \mathrm{t})\end{array}$ & $\begin{array}{c}\text { 全国総生産量 } \\
\text { に占める比率 }(\%)\end{array}$ \\
\hline 建築塗料 & 1,040 & 52 \\
自動車塗料 & 200 & 10 \\
木器塗料 & 100 & 5 \\
工業塗料 & 240 & 12 \\
特殊塗料およびその他 & 420 & 21 \\
\hline
\end{tabular}

表 112001 年度塗料生産

\begin{tabular}{|c|c|c|c|c|c|}
\hline & & \multirow{2}{*}{ 品 } & \multirow{2}{*}{ 目 } & \multicolumn{2}{|c|}{ 生 産 } \\
\hline & & & & 数量 $(\mathrm{t})$ & 前年比 (\%) \\
\hline \multicolumn{4}{|c|}{ ラッカー } & 24,694 & 91.5 \\
\hline \multicolumn{4}{|c|}{ 電気絶縁塗料 } & 32,758 & 78.0 \\
\hline \multirow[b]{7}{*}{ 合 } & \multirow{6}{*}{ 溶 } & \multirow{3}{*}{ アルキド樹脂系 } & ワニス・エナメル & 40,220 & 91.2 \\
\hline & & & 調合ペイント & 43,900 & 91.5 \\
\hline & & & さび止ペイント & 56,803 & 94.9 \\
\hline & & \multicolumn{2}{|c|}{ アミノアルキド樹脂系 } & 92,766 & 86.5 \\
\hline & & \multirow{2}{*}{ アクリル樹脂系 } & 常温乾燥型 & 62,975 & 91.1 \\
\hline & & & 焼付乾燥型 & 45,032 & 89.8 \\
\hline & \multirow{6}{*}{ 剂 } & \multicolumn{2}{|l|}{ エポキシ樹脂系 } & 109,660 & 98.4 \\
\hline \multirow[t]{2}{*}{ 成 } & & \multicolumn{2}{|l|}{ ウレタン樹脂系 } & 126,997 & 97.1 \\
\hline & & \multicolumn{2}{|c|}{ 不飽和ポリエステル樹脂系 } & 19,907 & 91.1 \\
\hline \multirow[t]{3}{*}{ 樹 } & & \multicolumn{2}{|l|}{ 船底塗料 } & 19,227 & 107.3 \\
\hline & & \multicolumn{2}{|l|}{ その他の溶剤系 } & 105,882 & 93.1 \\
\hline & & \multicolumn{2}{|l|}{ 溶剂系 計 } & 723,369 & 93.4 \\
\hline \multirow{8}{*}{ 塗 } & \multirow{4}{*}{ 水 } & \multicolumn{2}{|c|}{ エマルションペイント } & 141,523 & 99.9 \\
\hline & & \multicolumn{2}{|c|}{ 厚膜型エマルション } & 76,075 & 91.8 \\
\hline & & \multicolumn{2}{|l|}{ 水性樹脂采塗料 } & 146,810 & 97.4 \\
\hline & & \multicolumn{2}{|l|}{ 水系 計 } & 364,408 & 97.1 \\
\hline & 無 & \multicolumn{2}{|l|}{ 粉体塗料 } & 24,706 & 90.4 \\
\hline & 溶 & \multicolumn{2}{|c|}{ トラフィックペイント } & 103,803 & 96.4 \\
\hline & 剂 & \multicolumn{2}{|l|}{ 無溶剂 計 } & 128,509 & 95.2 \\
\hline & & \multicolumn{2}{|l|}{ 計 } & $1,216,286$ & 94.7 \\
\hline \multicolumn{4}{|c|}{ その他の塗料 } & 86,733 & 93.7 \\
\hline \multicolumn{4}{|c|}{ シンナー } & 424,550 & 94.1 \\
\hline \multicolumn{4}{|c|}{ 合計 } & $1,785,021$ & 94.1 \\
\hline
\end{tabular}


表 122001 年 4 月 2002 年 3 月塗料出荷数量表

（経済産業省統計調）

\begin{tabular}{|c|c|c|c|c|c|}
\hline \multicolumn{4}{|c|}{$\begin{array}{r}\text { 品 } \\
\end{array}$} & 計 & 前年合計 \\
\hline \multicolumn{4}{|c|}{ ラッカー } & 19,613 & 21,212 \\
\hline \multicolumn{4}{|c|}{ 電気絶縁塗料 } & 32,614 & 41,297 \\
\hline \multirow[b]{7}{*}{ 合 } & \multirow{6}{*}{ 溶 } & \multirow{3}{*}{ アルキド樹脂系 } & ワニス・エナメル & 41,600 & 46,114 \\
\hline & & & 調合ペイント & 48,235 & 52,388 \\
\hline & & & さび止ペイント & 59,747 & 63,017 \\
\hline & & \multicolumn{2}{|c|}{ アミノアルキド樹脂系 } & 89,944 & 102,850 \\
\hline & & \multirow{2}{*}{ アクリル樹脂系 } & 常温乾燥型 & 66,852 & 71,364 \\
\hline & & & 焼付乾燥型 & 46,199 & 51,725 \\
\hline & \multirow{3}{*}{$\begin{array}{l}\text { 剤 } \\
\text { 系 }\end{array}$} & \multicolumn{2}{|l|}{ エポキシ樹脂系 } & 127,756 & 130,946 \\
\hline 成 & & \multicolumn{2}{|l|}{ ウレタン樹脂系 } & 141,245 & 143,339 \\
\hline & & \multicolumn{2}{|c|}{ 不飽和ポリエステル樹脂系 } & 20,686 & 23,131 \\
\hline 樹 & & \multicolumn{2}{|l|}{ 船底塗料 } & 20,274 & 19,231 \\
\hline 脂 & & \multicolumn{2}{|l|}{ その他の溶剂系 } & 108,775 & 116,256 \\
\hline \multirow{9}{*}{$\begin{array}{l}\text { 塗 } \\
\text { 料 }\end{array}$} & & \multicolumn{2}{|l|}{ 溶剂系 計 } & 771,313 & 820,361 \\
\hline & & \multicolumn{2}{|c|}{ エマルションペイント } & 151,422 & 155,724 \\
\hline & 水 & \multicolumn{2}{|c|}{ 厚膜型エマルション } & 86,729 & 95,090 \\
\hline & 系 & \multicolumn{2}{|l|}{ 水性樹脂系塗料 } & 151,787 & 159,040 \\
\hline & & \multicolumn{2}{|l|}{ 水系 計 } & 389,938 & 409,854 \\
\hline & 無 & \multicolumn{2}{|l|}{ 粉体塗料 } & 30,727 & 32,392 \\
\hline & 溶 & \multicolumn{2}{|c|}{ トラフィックペイント } & 110,171 & 111,565 \\
\hline & 剤 & \multicolumn{2}{|l|}{ 無溶剤 計 } & 140,898 & . 143,957 \\
\hline & \multicolumn{3}{|c|}{ 計 } & $1,302,149$ & $1,374,172$ \\
\hline \multicolumn{4}{|c|}{ その他の塗料 } & 132,531 & 140,194 \\
\hline \multicolumn{4}{|c|}{ シンナー } & 444,260 & 471,197 \\
\hline \multicolumn{4}{|c|}{ 合計 } & $1,931,167$ & $2,048,072$ \\
\hline
\end{tabular}

表 13 日本の塗料企業の海外生産量

(単位：トン, \%)

\begin{tabular}{llrrrrrr}
\hline & 米国 & \multicolumn{1}{c}{ 欧州 } & 極東 & 東南アジア & その他 & 合計 & 90 年比 \\
\hline 1990 年 & 10,515 & 5,000 & 19,601 & 124,108 & 28,410 & 187,634 & 100.0 \\
1991 年 & 19,521 & 5,701 & 23,034 & 143,042 & 28,730 & 220,028 & 117.3 \\
1992 年 & 21,825 & 6,583 & 30,124 & 169,511 & 26,337 & 254,380 & 135.6 \\
1993 年 & 24,328 & 8,151 & 31,337 & 189,654 & 26,640 & 280,110 & 149.3 \\
1994 年 & 27,328 & 7,849 & 43,797 & 212,560 & 35,450 & 326,984 & 174.3 \\
1995 年 & 21,240 & 20,440 & 73,612 & 241,921 & 45,000 & 402,213 & 214.4 \\
1996 年 & 27,178 & 24,430 & 138,800 & 254,658 & 45,800 & 490,866 & 261.6 \\
1997 年 & 28,240 & 30,254 & 126,948 & 230,658 & 67,160 & 483,260 & 257.6 \\
1998 年 & 29,593 & 32,656 & 137,435 & 189,603 & 55,340 & 444,627 & 237.0 \\
1999 年 & 28,080 & 36,390 & 187,073 & 190,240 & 71,600 & 513,383 & 273.6 \\
2000 年 & 28,535 & 60,300 & 235,380 & 219,198 & 73,500 & 616,912 & 328.8 \\
\hline
\end{tabular}

（注）極東：中国, 香港, 韓国

東南アジア：シンガポール，マレーシア，タイ，インドネシア，フィリピン 